\title{
Change in physical and chemical characteristics related to the binomial time-temperature used in sous pasteurization see Tambaqui (Colossoma macropomum)
}

\author{
[Variação das características físico-químicas relacionadas ao binômio tempo-temperatura utilizado \\ na pasteurização de sous vide de tambaqui (Colossoma macropomum)] \\ H.C.A. Kato ${ }^{1}$, L.F.H. Lourenço ${ }^{2}$, E.A.F. Araújo ${ }^{2}$, C.L. Sousa ${ }^{2}$, M.R.S. Peixoto Joele ${ }^{3 *}$, \\ S.C.A. Ribeiro ${ }^{3}$ \\ ${ }^{1}$ Embrapa Pesca e Aquicultura, Palmas, TO \\ ${ }^{2}$ Universidade Federal do Pará /PPGCTA - Belém, PA \\ ${ }^{3}$ Instituto Federal de Educação, Ciência e Tecnologia do Pará, Campus Castanhal, PA
}

\begin{abstract}
The goal of this study was to evaluate sous vide fish and assess the influence of time and temperature on the pasteurization process through quality parameters. The raw material (tambaqui fillets) and the sous vide underwent physical, physicochemical, and microbiological analyses. A sauce was prepared containing soy sauce, water, horseradish and garlic flakes. The product's pasteurization parameters of time and temperature were defined according to a $2^{2}$ central composite rotatable design (CCRD), and the dependent variables were water holding capacity (WHC) and instrumental texture aiming at obtaining high WHC values for the product to maintain the desired juiciness. The microbiological analysis required by legislation have indicated that the fish fillets and sous vide were within de standard. The values of total coliforms found in the samples (fillets and sous vide) analyzed were below the critical level of $10^{2} \mathrm{CFU} / \mathrm{g}$. The counts of sulphite-reducing clostridia and psychrotrophic and mesophilic bacteria on plates in the samples were $<1 \times 10 \mathrm{CFU} / \mathrm{g}$. In conclusion, temperature was the most important factor in the pasteurization process, significantly contributing to the quality of the final product. The mathematical models proposed were considered predictive for each response.
\end{abstract}

Keywords: fish, tambaqui, texture, response surface

\section{RESUMO}

O objetivo deste estudo foi avaliar a influência do tempo e da temperatura no processo de pasteurização do sous vide de peixe por meio dos parâmetros de qualidade. Foram realizadas análises físicas, físicoquímicas e microbiológicas na matéria-prima (filé de tambaqui) e no sous vide. Foi preparado um molho contendo molho de soja, água, raiz forte e flocos de alho. Parâmetros de pasteurização do produto (tempo $x$ temperatura) foram definidos de acordo com um projeto de $2 \times 2$ rotativo composto central (DRCC), e as variáveis dependentes foram capacidade de retenção de água (CRA) e textura instrumental, visando à obtenção de altos valores de CRA para que o produto obtivesse a suculência desejada. As análises microbiológicas exigidas na legislação indicaram que a matéria-prima e o sous vide encontravam-se dentro dos padrões estabelecidos. Os valores de coliformes totais encontrados nas amostras (filés e sous vide) analisadas foram inferiores ao nível crítico de $10^{2} \mathrm{UFC} / \mathrm{g}$. As contagens de clostrídios sulfitorredutores e bactérias psicrotróficas e mesófilas em placas nas amostras foram $<1 \times 10$ UFC/g. Concluiu-se que a temperatura foi o fator mais importante no processo de pasteurização, contribuindo de forma significativa para a qualidade do produto final. Os modelos matemáticos propostos foram preditivos para cada resposta.

Palavras-chave: peixe, tambaqui, textura, superfície de resposta

Recebido em 30 de outubro de 2014

Aceito em 14 de julho de 2015

*Autor para correspondência (corresponding author)

E-mail: reginajoele@hotmail.com 


\section{INTRODUCTION}

The changes in consumers' eating habits, technological advances, and economic pressure have helped transform the food industry with an increasing demand for ready-to-eat products. The sous vide technique is one of the new product alternatives that fulfill these requirements. The process uses vacuum combined with controlled cooking to obtain a ready-to-eat product that can be consumed immediately or later when cooled/frozen. This process aims at a product with better color, flavor, texture, and nutrient retention characteristics than the traditional cooking processes, making for an attractive alternative for consumption (Nyati, 2000; Díaz et al., 2009).

Sous vide technology includes vacuum packaging and a thermal treatment comparable to pasteurization conditions. Temperatures between $54^{\circ} \mathrm{C}$ and $72^{\circ} \mathrm{C}$ are used and the product is stored at cooling/freezing temperatures so that an optimal balance can be obtained among longer shelf life, product microbiological safety, and the maintenance of fresh-food appearance, while preserving the nutritional contents (Schellekens, 1996. Countless studies have been carried out and indicate the viability of using the sous vide process with different types of meats and fish (Vaudagna et al., 2002; García-Linares et al., 2004; Díaz et al., 2010).

Fish is a great raw material for employing this technique on, as long as it is fresh and has good quality, without scales or spines (Baldwin, 2012). Salmon is the most widely used fish species in preparing sous vide and several studies show results on shelf life and sensory characteristics (González-Fandos et al., 2005; Díaz et al., 2009). Picouet et al. (2011) applied high-pressure processing (HPP) in salmon sous vide preparation at three different pressures $(210,310$, and $400 \mathrm{MPa}$ ) for $5 \mathrm{~min}$ at $10^{\circ} \mathrm{C}$ and concluded that, by using a pressure above $310 \mathrm{MPa}$, the product remains microbiologically stable for a range of six to eight days.

González-Fandos et al. (2005) concluded that the treatment at $90^{\circ} \mathrm{C}$ for 33 min inside the product is the most effective to assure safety and prolong trout (Oncorhynchus mykiss) sous vide shelf life while preserving its sensory characteristics. Nyati (2000), while studying the effects of temperatures of 3 and $8^{\circ} \mathrm{C}$ on the microbiological and sensory characteristics during sous vide storage, found a higher incidence of microorganisms and quality loss at higher temperatures.

Important meat quality aspects may include factors such as fat, water holding capacity, appearance, and nutritional value of these products. The concept of food quality implies texture/tenderness, juiciness, flavor, and aroma (Tornberg, 2005).

Tambaqui (Colossoma macropomum) (Cuvier, 1818 ) is a native species from the Amazon region and is considered an excellent farming fish since it has zootechnical and handling qualities that make a good yield possible. This species' high nutritional value and great economic and social importance in Latin America may be an alternative for supplying new market niches with ever more demanding consumers (Bombardelli et al., 2005; Brasil, 2008).

The use of fish for preparing sous vide can make way for new products to enter both nation and international markets. A product with good presentation and quality packaging can employ marketing strategies to reach a public which is seeking high-quality foods that are easy to prepare, which is a drive for the fishing industry (Souza, 2002).

The goal of this study was to assess the influence of time and temperature on the pasteurization process of fish sous vide through quality parameters.

\section{MATERIAL AND METHODS}

30 adult tambaqui (Colossoma macropomum) specimens with the same genetic origin were used, raised in masonry tanks in the Estação Experimental de Psicultura da Universidade Fereal Rural da Amazônia (UFRA).

The tambaqui were slaughtered at the place of collection through thermal shock by immersion in water at $2 \pm 1^{\circ} \mathrm{C}$ in an 170-liter expanded polystyrene $\left(\right.$ Styrofoam $^{\circledR}$ ) box after 24 hours in fasting and subjected to purging. Next, the fish were transported with scale ice to the Amazon Fish Industry (Indústria de Pescados Amazonas AMASA, Belém, PA, Brasil), where they were 
eviscerated, cleaned, and filleted on stainless steel tables with $5 \mathrm{ppm}$ chlorinated water.

The whole fish and the fillets were weighed with a Filizola (Filizola, São Paulo, SP, Brasil) digital scale so that the filleting process yield could be known. The fillets were stored in pairs inside polyethylene bags and $2 \mathrm{~kg}$ and $7 \mathrm{~cm}$ high cardboard boxes. Next, they underwent quick freezing in a plate freezer (Madef AP, São Paulo, SP, Brasil). The boxes were transported to the Laboratory of Fish and Meat Technology (LAPESCA) of the Federal University of Para (UFPA), where they were stored in a Brastemp (Whirlpool Latin America, São Paulo, SP, Brasil) freezer at $-26^{\circ} \mathrm{C}$ until processing.

The raw material and final product were analyzed for indicative microbiological quality according to the standards mandated by the current legislation through the RDC no. 12 (Brasil, 2001): coliforms at $45^{\circ} \mathrm{C}$, coagulase positive staphylococci and Salmonella. In addition, counts were also performed for total coliforms, mesophiles, psychrotrophic, and sulphite-reducing clostridia. All analyses followed the methodology described in the Compendium of Methods for the Microbiological Examination of Foods (Downes and Ito, 2001).
Product preparation followed the Good Practices in Food Preparation, beginning with the thawing of the fillets under cooling and standardization into pieces of approximately $5 \times 7 \times 2.5 \mathrm{~cm}$, using the average size of the fillets' lumbar portion. A sauce containing $62 \%$ soy sauce (Tozan, São Paulo, SP), 30\% water, 5\% horseradish (Companhia das Ervas, São Paulo, SP), and 3\% scale garlic (Companhia das Ervas, São Paulo, SP) was prepared. Portions of about $200 \mathrm{~g}$ of fish were placed in $20 \times 25 \times 18 \mathrm{~cm}$ nylon/smooth coextruded polyethylene (Solupack, Barueri, São Paulo, SP) along with $50 \mathrm{~g}$ of sauce (at a ratio of $1: 4$ of fish) and $10 \mathrm{~mL} 2 \%$ sodium lactate. Next, the packages were vacuum sealed in FlexPack 3340 side-weld pouches with a FastVac F200 (São Paulo/SP) sealer according to Baldwin (2012).

The product was pasteurized in a Quimis (model Q-350-2, Diadema/SP/Brasil) double boiler using the times and temperatures set by the experiment design (Table 1). The immersion time only started being recorded after 4 minutes and 38 seconds, when the center of the piece reached the processing temperature. The inner temperature during pasteurization was measured with a thermocouple (Ghazala et al., 1995; Baldwin, 2012). Immediately after the thermal treatment, the samples were cooled in ice water down to $0{ }^{\circ} \mathrm{C}$ and stored at cooling temperature $\left(1 \pm 1^{\circ} \mathrm{C}\right)$.

Table 1. Levels of the process variables used in the central composite rotatable design

\begin{tabular}{lccccc}
\hline \multicolumn{1}{c}{ Process variables } & -1.41 & -1 & 0 & +1 & +1.41 \\
\hline Temperature $(\mathrm{T}){ }^{\circ} \mathrm{C}$ & 55.9 & 60 & 65 & 70 & 74.1 \\
Time $(\mathrm{t})$ minutes & $75^{\prime}$, & 10 & 12.5 & 15 & $175^{\prime}{ }^{\prime}$ \\
\hline
\end{tabular}

The parameters of time and temperature of the product's pasteurization were defined according to a central composite rotatable design (CCRD) $2^{2}$, and the dependent variables used were water holding capacity (WHC) and instrumental texture (Table 2) aiming at obtaining high WHC values for the product to maintain the desired juiciness according equation 1.

$$
\left.r(T, t)=b_{1} t+b_{2} T+b_{11} t^{2}+b_{22} T^{2}+b_{12} t T \text { (eq. } 1\right)
$$

The results obtained were evaluated through the hierarchy of the effects estimate and analysis of variance $(\mathrm{P} \leq 0.05)$. The best process condition was defined with the aid of response surface graphs and contour curves.

The Water Holding Capacity (WHC) was determined in $2.5 \mathrm{~g}$ samples placed between two round filter papers $5.5 \mathrm{~cm}$ in diameter, $200 \mu \mathrm{m}$ thick, and $80 \mathrm{~g} / \mathrm{m}^{2}$ grammage. Next, the samples were placed between two square polyurethane plates over which a $5 \mathrm{~kg}$ weight rested for five minutes, applying uniform pressure across the whole area. After that, the sample and the papers were weighed and the results were expressed as a percentage (Hamm, 1960). 
In the processing of the experimental design data to determine the binomial time/temperature pasteurization the program Statistica version 5.0 was used through the following tools: Verification of significant effects $(\mathrm{P} \leq 0.05$ or values next), Analysis of Variance (ANOVA); Response Surface Methodology.

The Instrumental Texture (TI) was measured by a QTS Texture Analyzer (Brookfield) and determined the firmness (consistency) parameter according to Sigurgisladottir et al. (1999) with the following analysis parameters: ambient temperature; compression force measure $(\mathrm{N})$, testing velocity: $2.0 \mathrm{~mm} \mathrm{~s}^{-1}$; trigger point: $0.1 \mathrm{~N}$; distance: $214 \mathrm{~mm}$; target value: $20 \mathrm{~N}$; and probe: $70 \times 3 \mathrm{~mm}$ single blade. The fillets were cut into $2 \times 2 \times 1.5 \mathrm{~cm}$ pieces for this analysis.

\section{RESULTS AND DISCUSSION}

The results of the microbiological analyses for coliforms at $45^{\circ} \mathrm{C}$, Salmonella, and coagulase positive staphylococci carried out on the fish fillets and sous vide were within the standards defined by the legislation (Brasil, 2001).

The values of total coliforms found in the samples (fillets and sous vide) analyzed were below the critical level of $10^{2} \mathrm{CFU} / \mathrm{g}$, a value that indicates contamination problems in refrigerated or frozen fish-derived products or even pre-cooked fish,breaded or not.
The counts of sulphite-reducing clostridia and psychrotrophic and mesophilic bacteria on plates in the samples (fillets and sous vide) were $<1 \times 10$ $\mathrm{CFU} / \mathrm{g}$. Although Brazilian legislation does not set limits for psychrotrophic and mesophilic bacteria, large populations may shorten the fish product's lifetime (Kirschink and Viegas, 2004). The International Comission on Microbiological Specification for Foods - ICMSF (1998) sets the limit of $10^{7} \mathrm{UFC} / \mathrm{g}$ for standard counts in aerobic microorganism plates. Hence, the values found in the samples were below the recommended limit for this group of microorganisms.

Raw materials with low microbial counts are fundamental to ensure the safety of sous vide, if the packaging is appropriate avoiding postprocess contamination. In this study, the satisfactory microbiological results of sous vide, indicate that the processing was done within proper hygiene standards.

The tambaquis underwent the purging process prior to slaughter for a clean gastrointestinal tract. According to Soccol et al. (2005), that reduces raw-material contamination. Tab. 2 shows the WHC and instrumental texture values obtained after the pasteurization process of the tambaqui fillets processes with the sous vide technique.

Table 2. Water Holding Capacity (WHC) and instrumental texture results for the different pasteurization conditions

\begin{tabular}{|c|c|c|c|c|}
\hline \multirow[b]{2}{*}{ Trial } & \multicolumn{2}{|c|}{ Coded values } & \multirow{2}{*}{$\begin{array}{l}\text { Water holding capacity } \\
\text { (WHC) }(\%)\end{array}$} & \multirow{2}{*}{$\begin{array}{l}\text { Instrumental } \\
\text { Texture }(\mathrm{N})\end{array}$} \\
\hline & Time $(\mathrm{t})$ & Temperature $(\mathrm{T})$ & & \\
\hline 01 & -1 & -1 & 84.55 & 16.91 \\
\hline 02 & 1 & -1 & 85.12 & 16.96 \\
\hline 03 & -1 & 1 & 83.49 & 15.21 \\
\hline 04 & 1 & 1 & 83.33 & 15.58 \\
\hline 05 & -1.41 & 0 & 85.87 & 15.89 \\
\hline 06 & 1.41 & 0 & 85.92 & 15.96 \\
\hline 07 & 0 & -1.41 & 82.17 & 15.23 \\
\hline 08 & 0 & 1.41 & 85.89 & 15.92 \\
\hline 09 & 0 & 0 & 84.26 & 17.53 \\
\hline 10 & 0 & 0 & 85.40 & 15.72 \\
\hline 11 & 0 & 0 & 84.71 & 16.31 \\
\hline
\end{tabular}

The results of the statistical analysis for WHC and instrumental texture are seen in Tab. 3. The effects of the linear, quadratic, and iteration factors, shown in bold, indicate that the factors are significant at $95 \%$ confidence level $(\mathrm{P} \leq 0.05)$. 
Table 3. Effects, regression coefficients, and analyses of variance for water holding capacity (WHC) and texture

\begin{tabular}{|c|c|c|c|c|c|c|c|c|}
\hline Response & Factors & Effects & $\begin{array}{c}\text { Regression } \\
\text { Coefficients }\end{array}$ & $\begin{array}{l}\text { Standard } \\
\text { Error }\end{array}$ & $P$ & $\mathrm{R}^{2}$ & $\begin{array}{c}\mathrm{F} \\
\text { model }\end{array}$ & $\begin{array}{l}\text { Lack } \\
\text { of fit }\end{array}$ \\
\hline \multirow{5}{*}{ WHC } & $b_{0}$ & 85.90 & 85.90 & 0.016 & & 0.99 & 1412.2 & n.s. \\
\hline & $\begin{array}{l}\text { Linear (L) } \\
b_{1} \\
b_{2}\end{array}$ & $\begin{array}{c}0.428 \\
-1.453\end{array}$ & $\begin{array}{c}0.214 \\
-0.726\end{array}$ & $\begin{array}{l}0.016 \\
0.016\end{array}$ & $\begin{array}{l}0.002 \\
0.000\end{array}$ & & & \\
\hline & $\begin{array}{l}\text { Quadratic } \\
\text { (Q) }\end{array}$ & & & & & & & \\
\hline & & $\begin{array}{l}-0.846 \\
-2.699\end{array}$ & $\begin{array}{l}-0.423 \\
-1.349\end{array}$ & $\begin{array}{l}0.020 \\
0.020\end{array}$ & $\begin{array}{l}0.000 \\
0.001\end{array}$ & & & \\
\hline & $\begin{array}{l}\text { Interation } \\
b_{12}\end{array}$ & -0.208 & -0.104 & 0.023 & 0.012 & & & \\
\hline \multirow{4}{*}{ Texture } & $b_{0}$ & 15.958 & 15.958 & 0.0249 & & 0.99 & 164.52 & n.s. \\
\hline & $\begin{array}{l}\text { Linear (L) } \\
b_{1} \\
b_{2}\end{array}$ & $\begin{array}{l}-0.2888 \\
-1.5855\end{array}$ & $\begin{array}{l}0.144 \\
0.793\end{array}$ & $\begin{array}{l}0.0249 \\
0.0249\end{array}$ & $\begin{array}{l}0.0073 \\
0.0002\end{array}$ & & & \\
\hline & $\begin{array}{l}\text { Quadratic } \\
\text { (Q) } \\
b_{11} \\
b_{22}\end{array}$ & $\begin{array}{l}0.0749 \\
0.4421 \\
\end{array}$ & $-\overline{210}$ & $\begin{array}{l}0.0297 \\
0.0297\end{array}$ & $\begin{array}{c}\text { n.s. } \\
0.0045\end{array}$ & & & \\
\hline & $\begin{array}{l}\text { Interation } \\
b_{12}\end{array}$ & -0.2100 & 0.105 & 0.0351 & 0.0268 & & & \\
\hline
\end{tabular}

It is seen that, except for time (L), all other parameters had a negative effect, temperature (L and Q) was the factor that had the greatest effect on water holding capacity. Water holding capacity is influenced by structural changes in proteins, fibril swelling, and the distribution of liquid between the intra- and extra-cellular spaces. Fish is cooked so that its texture and flavor change and also to destroy food pathogens. The fish's muscle flakes and the collagen is converted into gelatin at around 46$49{ }^{\circ} \mathrm{C} / 115-120{ }^{\circ} \mathrm{F}$ (Belitz et al., 2009). This temperature is too low, however, to destroy any food pathogens. Although the FDA (2011) usually recommends fish pasteurization, which reduces all parasites and non-spore-forming pathogens to a safe level, that does not reduce the risk of the hepatitis A virus (HAV) or shellfish norovirus infection. Ofstad et al. (1993), while analyzing salmon and cod fillets cooked at temperatures of 50 to $70^{\circ} \mathrm{C}$, found an increase in WHC value for temperatures above $60{ }^{\circ} \mathrm{C}$ and stated that this behavior is due to the structural changes that take place in the conjunctive tissue. Table 3 indicates that the coded mathematical model can be used to describe the WHC behavior within the experimental range studied since it had a significative and predictive regression, according to what Box and Wetz (1973) suggested, and a lack of non-significative adjustment, with a coefficient of determination $\left(\mathrm{R}^{2}\right)$ of 0.99 .

The Figure 1 shows the response surface and level curve generated through the proposed model, considering the midpoints of the times and temperatures where a variation in WHC is seen as a function of the variation in the parameters studied.

The difference between the minimum and maximum values (Table 2) of the results obtained in the instrumental texture analysis related to consistency (hardness) was approximately $13 \%$. Cooking temperature can impact the diameter of the muscle fiber, as well asfactors such as $\mathrm{pH}$ and presence of $\mathrm{NaCl}$, which may influence fish texture (Dunajski, 1979). 


\section{Change in physical...}
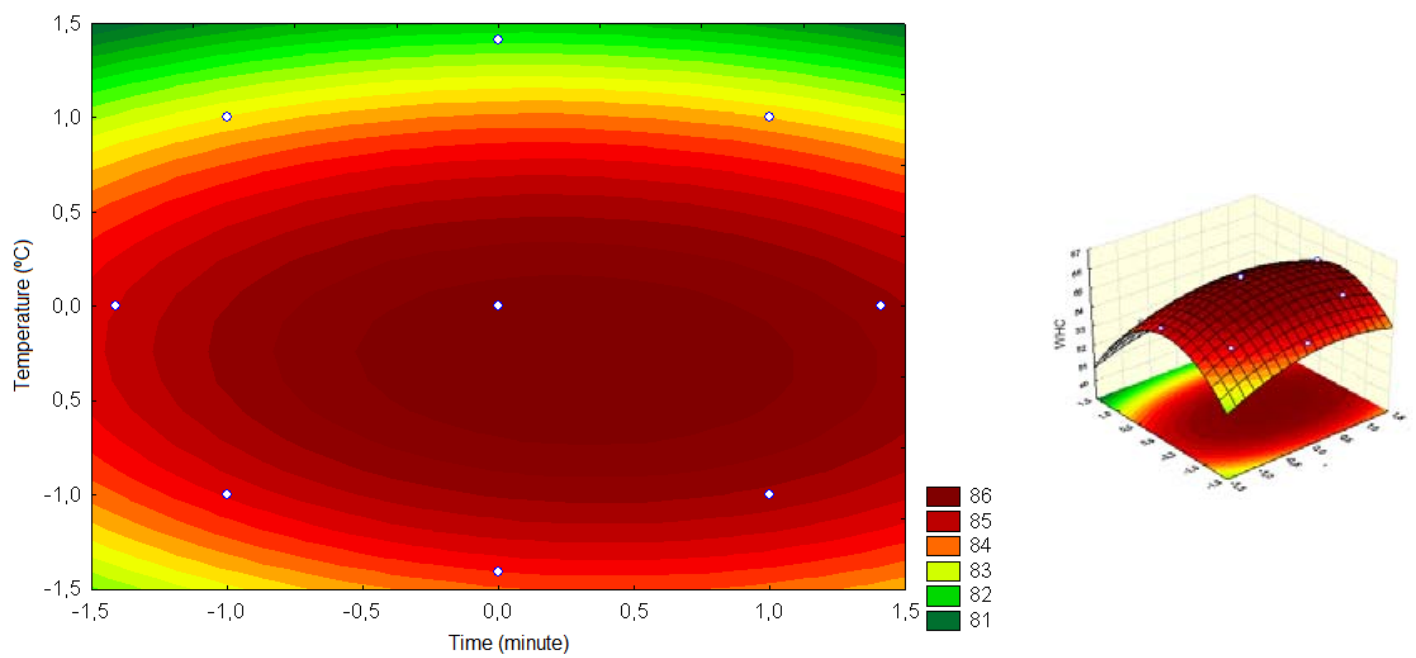

Figure 1. Response surface and level curve for WHC relating pasteurization time (min) and temperature $\left({ }^{\circ} \mathrm{C}\right)$ of tambaqui sous vide fillets.

Table 3 shows that the quadratic term of time was the only one not to have a significant $(\mathrm{P}>0.05)$ influence on the response. The linear term of temperature indicated that at around 65 ${ }^{\circ} \mathrm{C}$ the product's texture value dropped more markedly.

Taking into account that the sauce used in sous vide preparation in the current study was soysauce based (acid), Laakkonen et al. (1973) and Özden (2005) found that different marinating types lead to changes in the conjunctive tissue

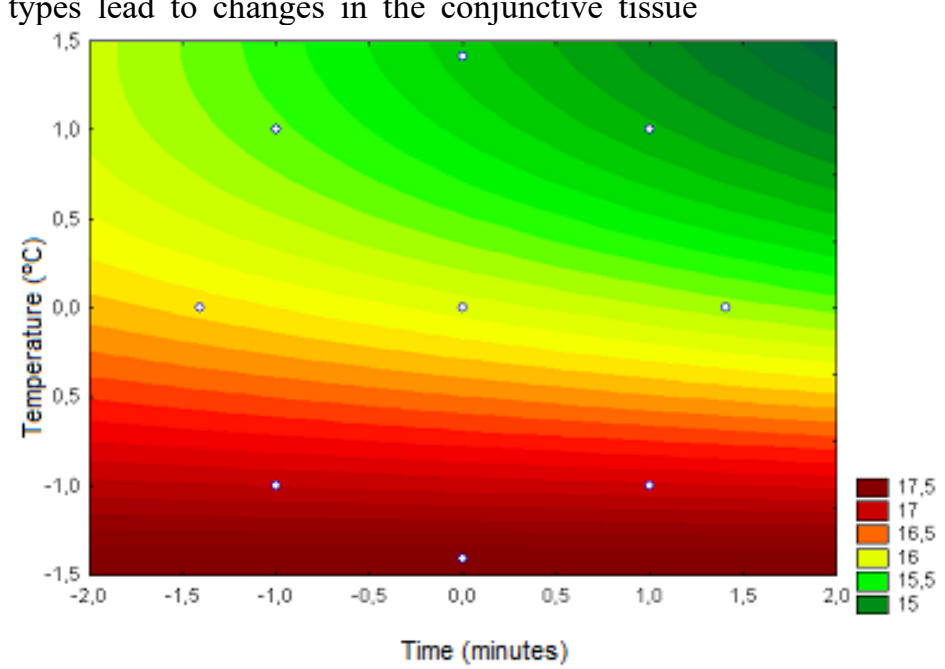

solubilization standard, thus causing different impacts on texture and quality of fillets undergoing this technique.

It was found that the model proposed can be considered appropriate to describe the texture behavior at the studied range since it also had a significant regression and no non-significant adjustment. Figure 2 shows the response surface and level curve generated through the proposed model.

Figure 2. Response surface and level curve for texture relating pasteurization time (min) and temperature $\left({ }^{\circ} \mathrm{C}\right)$ of tambaqui sous vide fillets. 
Several authors report a linear decrease in muscle texture starting at $60^{\circ} \mathrm{C}$ (Palka and Daun, 1999; Vaudagna et al., 2002; Garcia-Segovia et al., 2007), a similar behavior to the one seen in Figure 2.

According to Bailey and Light (1989), a significant reduction in texture can take place during cooking of different muscles at temperatures between 40 and $50^{\circ} \mathrm{C}$, which corresponds to the denaturation of myofibrillar proteins. A second, more marked reduction is seen starting at 65 to $70^{\circ} \mathrm{C}$, when the shortening of the fibers and actomyosin dehydration are intensified.

Therefore, in order for a final product to be obtained with the typical firmness of a fresh product, thus avoiding the firmness of raw fish, the process must be carried out at a temperature around the central point $\left(60^{\circ} \mathrm{C}\right)$ combined with the time across the range of the study.
The results for instrumental texture had an average of $20.29 \mathrm{~N}$ for the hardness parameter. The hardness of a muscle may be related to the freshness index and greater hardness may indicate muscle quality deterioration. This behavior can be especially marked in species raised in captivity compared to species captures in the wild due to differences related to stress at capture and slaughter.

The hardness values greatly varied for the in natura tambaqui fillets in this study, similarly to the values by Barroso et al. (1998), who found a coefficient of variance of $20 \%$ and $27 \%$ when analyzing the texture of hake and blue whiting, respectively. Those authors attribute this variability to the structural differences between the species' muscles. Regarding the graphical representation of texture, Jonsson et al. (2001) state that appropriate hardness measurements result in a markedly concave curve, similar to the one obtained in this study, as can be seen in Figure 3.

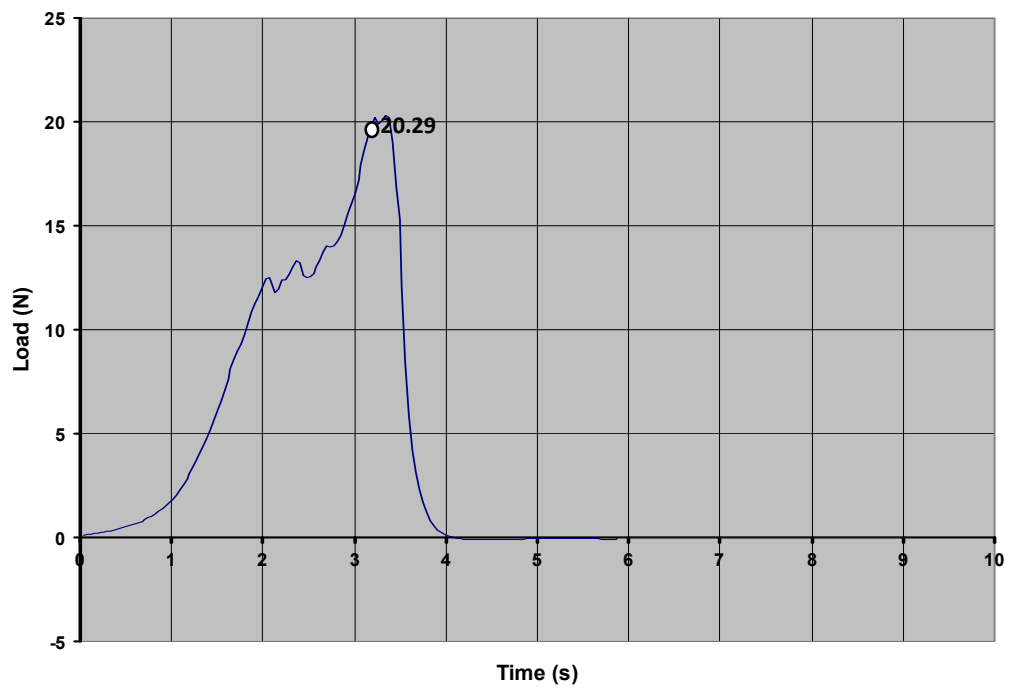

Figure 3. Variation in hardness for in natura tambaqui sample as a function of the time of analysis.

\section{CONCLUSION}

The sous vide prepared at $65^{\circ} \mathrm{C}$ for $12.5 \mathrm{~min}$ showed the best results for juiciness (WHC) and textures close to the characteristic consistency of fresh, but far from the consistency similar to raw fish. Temperature was the most important factor in the pasteurization process, significantly contributing to the quality of the final product. The results of microbiological analyzes indicated that the processing was done in adequate sanitary conditions. The mathematical models proposed were considered predictive for each response.

\section{ACKNOWLEDGEMENTS}

This study received financial support from FINEP/SEBRAE, PROPESP (Research Rectory) and $\mathrm{CNPq} /$ Brazil (National Council for Scientific and Technological Development). 


\section{REFERENCES}

BAILEY, A.J.; LIGHT, N.D. The role of connective tissue in determining the textural quality of meat. p.170-194. In: BAILEY, A.J.; LIGHT, N. D. (Eds.). Connective tissue in meat and meat products. London: Elsevier Publishing, 1989.

BALDWIN, D.E. Sous vide cooking: a review. Internal J. Gastron. Food Sci., v.11, p.15-30, 2012.

BARROSO, M.; CARECHE, M.; BARRIOS, L.; BORDERIAS, A.J. Frozen hake fillets quality as related to texture and viscosity by mechanical methods. J. Food Sci., v.63, p.793-796, 1998.

BELITZ, H.D., GROSCH. W.; SCHIEBERLE, P. Food chemistry. 4.ed. Berlin: Springer, 2009.

BOMBARDELLI, R.A.; SYPERRECK, M.A.; SANCHES, A. Present situation and perspectives for consumption, processing and aggregation of value to fish. Arch. Vet. Sci. Zool., v.82, p.181$195,2005$.

BOX, G.E.P.; WETZ, J. Criteria for judging adequacy of estimation by an approximate response function. Madison: University of Wisconsin, 1993. 92p. (Technical Report, n 9).

BRASIL Ministério da Pesca e Aquicultura. Estatística de Pesca e Aquicultura. Pesca e Aquicultura -Brasil Boletim Estatísitca 2008 e 2009. [acessado outubro 2013]. Disponível em: http://www.mpa.gov.br/index.php/informacoes-eestatisticas/estatistica-da-pesca-e-aquicultura.

Acessado em out 2013.

BRASIL. Ministério da Saúde. Aprova o Regulamento Técnico com Resolução RDC n 12, de 02 de jan de 2001. Padrões microbiológicos para alimentos. Diário Oficial da República Federativa do Brasil, 2001.

DÍAZ, P.; GEMA NIETO, G.; BAÑON, S.; GARRIDO, M.D. Determination of shelf life of sous vide salmon (Salmo salard) based on sensory attributes. J. Food Sci., v.74, p.S371S376, 2009.

DÍAZ, P., GARRIDO, M.D.; BAÑÓN, S. The effects of packaging method (vacuum pouch vs. plastic tray) on spoilage in a cook-chill porkbased dish kept under refrigeration. Meat Sci., v.84, p.538-544, 2010.
DOWNES, F.P.; ITO, K. Compendium of methods for the microbiological examinations of foods. 4.ed. Washington: APHA, 2001.

DUNAJSKI, E. Texture of fish muscle. J. Text. Stud., v.10, p.301-318. 1979.

FISH and fishery products hazards and controls guidance. 4.ed. Silver Spring: FDA, 2011. (Technical Report).

GARCÍA-LINARES, M.C.; GONZALEZFANDOS, E.; GARCÍA-FERNÁNDEZ, M.C.; GARCÍA-ARIAS, M.T. Microbiological and nutritional quality of sous vide or traditionally processed fish: Influence of fat content. J. Food Qual., v.27, p.371-387. 2004.

GARCIA-SEGOVIA, P.; ANDRES-BELLO, A.; MARTINEZ-MONZOÉ, J. Effect of cooking method on mechanical properties, color and structure of beef muscle (M. pectoralis). J. Food Engin., v.80, p.813-821. 2007.

GHAZALA, S.; RAMASWAMY, H.S.; SMITHB, B.J.P.; SIMPSOD, M.V. Thermal process simulations for sous vide processing of fish and meat foods. Food Res. Intern., v.28, p.117-122. 1995.

GONZÁLEZ-FANDOS, E.; VILLARINORODRÍGUEZ, A.; GARCÍA-LINARES, M.C. et al. Microbiological safety and sensory characteristics of salmon slices processed by sous vide method. Food Control, v.16, p.75-85, 2005.

HAMM, R. Biochemistry of meat hydration. Adv. Food Res., v, 10, p.463, 1960.

JONSSON, A.; SIGURGISLADOTTIR, S.; HAFSTEINSSON, H.; KRISTBERGSSON, K.. Textural properties of raw Atlantic salmon (Salmo salar) fillets measured by different methods in comparison to expressible moisture. Aquacult. Nutr., v.7, p.81-89. 2001.

KIRSCHINK, P.G.; VIEGAS, E.M.M. Changes in the quality of freshwater prawn Macrobrachium rosenbergii during storage in ice. Food Sci. Techn., v.24, p.407-412. 2004.

LAAKKONEN, E. Factors affecting tenderness during heating of meat. In: CHICHESTER, C.O.; MRAK, E.M.; Stewart, G.F. (Eds.). Advances food research. New York: Academic Press, 1973. P.257-323. 
MICROORGANISMS in foods. Toronto: University of Toronto, 1988.

NYATI, H. An evaluation of the effect of storage and processing temperature on the microbiological status of sous vide extended shelf-life products. Food Control, v.11, p.471476, 2000.

OFSTAD, R.; KIDMAN, S.; MYKLEBUST, R.; HERMANSSON, A.M. Liquid holding capacity and structural changes during heating of fish muscle: Cod (Gadus morhua L.) and salmon (Salmo salar). Food Qual., v.12, p.163-174. 1993.

ÖZDEN, Ö. Changes in amino acid and fatty acid composition during shelf-life of marinated fish. J. Sci. Food Agric., v.85, p.2015-2020. 2005.

PALKA, K; DAUN, H. Changes in texture, cooking losses, and myofibrillar structure of bovine $M$. semitendinosus during heating. Meat Sci., v.51, p.237-224. 1999.

PICOUET, P.A.; COFAN-CARBO, S.; VILASECA, H. et al. Stability of sous-vide cooked salmon loins processed by high pressure. Innov. Food Serv. Emer. Techn., v.12, p.26-31. 2011.
SCHELLEKENS, M. New research issues in sous-vide cooking. Trends in Food Sci. and Technol., v.7, p.256-262, 1996.

SIGURGISLADOTTIR, S.; HAFSTEINSSON, H.; JONSSON, A. et al. Textural properties of raw salmon fillets as related to sampling method. J. Food Sci., v. 64, p.99-104. 1999.

SOCCOL, M.C.H.; OETTERER, M.; GALLO, C.R. et al. Effects of modified atmosphere and vacuum on the shelflife of tilapia (Oreochromis niloticus) fillets. Braz. J. Food Tech., v.8, p.7-15. 2005.

SOUZA, M.L.R. Comparison of Six Filleting Methods and their Relation with Fillet Yield and By-products of Nile Tilapia (Oreochromis niloticus) Processing.Brazilian. J. Anim. Sci., v.31, p.1076-1054. 2002.

TOMBERG, E. Effects of heat on meat proteins Implications on structure and quality of meat products. Meat Sci., v.70, p.493-508. 2005.

VAUDAGNA, S.R.; SANCHEZ, G.; NEIRA, M.S. et al. et al. Sous vide cooked beef muscles: effects of low temperature-long time (LT-LT) treatments on their quality characteristics and storage stability. Inter. J. Food Sci. Techn., v.37, p.425-441, 2002. 